\title{
Evaluation of the internal structure of the Serbian version of the Big Five Questionnaire for Children and the development of a short form (SBFQ-C-29): A preliminary study
}

\author{
Stanislava Popov ${ }^{1}$, Jelena Sokić \\ Faculty of Sport and Tourism, Educons University, Novi Sad \\ Danijela Radović \\ Pedagogical Institute of Vojvodina, Novi Sad
}

\begin{abstract}
The personality characteristics of children and adolescents explained by the Big Five model have been studied much less than the personality characteristics of adults. One of the rare self-assessment personality instruments for the preadolescent and adolescent age is the Big Five Questionnaire for Children (BFQ-C). The aim of this study is an evaluation and presentation of the latent structure and some psychometrical characteristics of the BFQ-C in the Serbian language. The sample consisted of 881 participants ( $54 \%$ female) who attended the final grades of primary and the initial grades of secondary schools $(M=14$ years, $S D=.99)$. The original model, previously addressed across different cultures and languages, was tested through CFA. The hypothesized model did not obtain satisfactory fit indices. Following these results, the sample was randomly divided into two datasets. We opted for further exploration of the Serbian version of BFQ-C's latent structure and the development of its shorter version. The final result is the 29-item questionnaire solution (SBFQ-C-29), with loadings on five factors with satisfactory internal consistency, homogeneity, and adequacy, consistent with the previous studies addressing different cultures and languages.
\end{abstract}

Key words: BFQ-C, internal structure, Serbian version

\section{Introduction}

The Big Five model assumes five fundamental dimensions of personality traits: Neuroticism (or Emotional instability), Extraversion, Conscientiousness,

1 stanislava.popov@tims.edu.rs 
Agreeableness and Openness to Experience (or Intellect). Goldberg (1993) introduced the term Big Five by referring to the analysis of language in describing personality, since it had been shown that the way people define themselves by words can be reduced to five dimensions which usually predict human behaviour (John \& Srivastava, 1999). The analysis of language and psychological instruments has operationalized these dimensions in various ways so far, which implies the existence of several questionnaires based on this model (Čolović, Smederevac, \& Mitrović, 2005). The model based on five dimensions is also known as the Five-Factor Model of personality. The most common description of "the Big Five" is Neuroticism (Emotional instability) as a contrast to emotional stability, Extraversion as sociability and activity; Conscientiousness as persistence in work and achievement, Agreeableness as kindness in social relations and helping others, and, finally, Openness, which is the opposite of rigidity and refers to intellectual and artistic curiosity (Costa \& McCrae, 1992).

The personality characteristics of children and adolescents explained by the Big Five model have been investigated much less than the personality characteristics of adults. Personality characteristics of children are commonly assessed according to the reports of parents and teachers, and rarely according to self-assessment (Oliver \& Herve, 2015). Questionnaires based on self-assessment are rare (which is undoubtedly caused by the minor age of potential respondents, except adolescents), and until recently, Eysenck's JEPQ (Eysenck \& Eysenck, 1975) was used most commonly. However, there is growing evidence that the Five-Factor Model is relevant for understanding and predicting child functioning, in the context of school achievement, externalizing and internalizing behavioural problems (Muris, Meesters, \& Diederen, 2005). One of the first self-assessment personality instruments for the preadolescent and early adolescent age (8-14 years) with the mentioned theoretical basis is the Big Five Questionnaire for Children (BFQ-C; Barbaranelli, Caprara, Rabasca, \& Pastorelli, 2003). The questionnaire originally contains 65 items, with 13 items for each dimension. After the analysis of 285 adjectives for personality description, the authors consulted parents and teachers to choose the best ones for describing their child or student. Choosing from the selected adjectives, the authors created items for the questionnaire and repeatedly evaluated it in various pilot studies. Finally, the instrument proved to be a good measure of personality traits based on the Big Five model (Gresham \& Gullone, 2012; Muris et al., 2005). However, the original Italian version of the instrument was translated into several languages (Greek, Dutch, German, Spanish, French and American English), and it was moderately supported in cross-cultural adaptations. Replicating the five-factor structure in other languages is recommended for the further support of this instrument (Gaio, 2012).

Initial tests and applications of the instrument in other languages yielded encouraging results. For example, in the Dutch translation (Muris et al., 
2005, $N=222,12-17$ years old), the factor structure proved to be mostly in agreement with the original instrument, except for minor overlaps between Extraversion, Openness and Conscientiousness. The internal consistency of dimensions also proved to be at a satisfactory level (.70-.80). However, the limitation of the study was a small sample size for an examination of the factor structure of the instrument. The French (Olivier \& Herve, 2015, $N=386,8-14$ years old, Cronbach's $\alpha=.80-.86$ ) and Greek translation (Kokkinos \& Markos, 2015, $N=1.103,10-12$ years old, Cronbach's $\alpha=.75-.82$ ) also repeated the original structure of the instrument satisfactory internal consistency of the dimensions. However, in addition to the small sample for factor analysis in some of these studies (e.g. Gorsuch (1983) recommended sampling at least five, but Nunnally (1978) suggested at least ten times as many subjects as variables), it is evident that the sample in the research included a different age range of respondents. It is an essential matter to note for the late childhood and adolescent age, given that the respondents aged 8 and 17 are in different stages of cognitive development, and they have different interests, daily obligations and degree of independence. Hence, the question is whether the same self-assessment scale could validly examine their personality traits. In addition, not all studies have confirmed a clear five-factor structure, and the overlap between the Extraversion, Openness, and Conscientiousness dimensions has been repeated several times. For example, a study on a Spanish sample (Holgado-Tello et al., 2009, $N=852,8-15$ years old) took the original ordinal metric into account when examining the dimensionality of the BFQ-C, using factor analysis based on a matrix of polychoric correlations. The results obtained through EFA replicated the original fivefactor structure, but the results of CFA were slightly better consistent with the four-factor structure. Authors recommended further research in order to examine whether Openness should be maintained as an independent factor (the five-factor model), or it would be better to distribute its items among the Extraversion and Conscientiousness (the four-factor model). Similar results were obtained on the Spanish version of the BFQ-C tested in a sample of Argentinean adolescents (Cupani \& Ruarte, 2008, $\mathrm{N}=598,13-15$ years old). The results showed that a five-factor structure fitted the population studied, but several items exhibited factorial weighs shared with two or more factors, generating a complex factorial structure. The results of the CFA demonstrated that the five-factor structure fitted the data only when items within subscales were used as operational indexes. Authors recommended further investigations in order to assess the internal structure of the BFQ-C (Cupani \& Ruarte, 2008).

However, in addition to the solid psychometric characteristics and moderately confirmed internal structure, the instrument proved to be too long for the target population, especially when it is administered in a battery with other instruments (Markos \& Kokkinos, 2017, Pejić,Tenjović, \& Knežević, 2014). For that reason, some researchers have tried to develop its shorter 
version (Markos \& Kokkinos, 2017). The Greek BFQ-C-Short Form is a 30item scale assessing the Big Five personality factors of children and adolescents aged between 8 and 15. Each factor consists of 6 items, with a satisfactory internal consistency ranging from .79 to .84 (Markos \& Kokkinos, 2017).

The primary goal of this study is an evaluation of the internal structure of the Serbian version of the BFQ-C and some of its psychometric properties. To our knowledge, there have been no such attempts so far, although the BFQ-C has been extensively used in several European languages.

\section{Method}

\section{Sample}

The sample consisted of 881 participants from several municipalities in the Autonomous Province of Vojvodina (hereinafter Vojvodina), the northern province of Serbia, characterized by cultural, ethnic and social diversity ${ }^{2}$. Participants were students of all officially represented nationalities attending the final grades of the primary (13 to 14 years old) and the first two grades of secondary schools (15 to16 years old) $(M=14.08, S D=.73)$. Such sampling tended to satisfy the conditions of representativeness for Vojvodina in which the research was conducted, but not for the whole of Serbia. ${ }^{3}$

Gender structure of the sample was relatively balanced (54\% female). ${ }^{4}$ The research included students from 18 schools. Taking into account that the sample consisted of minor age participants, it was necessary to obtain approval for research from the authorities, such as the Councils of Parents and school management. To obtain these permits, we had a recommendation and support from the Pedagogical Institute of Vojvodina that ensured that legal and ethical norms were met. Each school approved the participation of students in the research. Representatives of the Councils of National Minorities in Vojvodina assisted in recruiting the sample. Students voluntarily participated in the research and had the opportunity to withdraw from participation, in which case their data were not included in the final sample.

2 The largest number of respondents are students of Serbian nationality (42\%), followed by Hungarian (16\%), then Slovak (12\%) and Romanian nationality (12\%). The rest of the respondents are students of other national minorities in Vojvodina.

3 This study is part of a more extensive study that aimed to examine the attitudes of students and their parents about the importance of knowing other languages from the immediate environment, given that Vojvodina is a multinational and multilingual environment.

4 The calibrated sample consisted of $53.6 \%$ girls, while the age range was distributed as following: 13 years (21.6\%), 14 years (33.6\%), 15 years $(34.8 \%)$ and 16 years $(9.4 \%)$. The cross-validated sample consisted of $61.4 \%$ girls, age range: 13 years $(24.9 \%), 14$ years (9.4\%), 15 years $(28.5 \%)$ and 16 years $(16.7 \%)$. 
In the previous part of the study, which is not the subject of this paper, their parents also participated (referred to Popović \& Radović, 2015).

\section{Instruments}

The Big Five Questionnaire for Children (BFQ-C; Barbaranelli et al., 2003) consists of 65 items assessing the five factors of personality in children (9 to 14 years old):

- Energy/Extraversion (E/E);

- Agreeableness (A);

- Conscientiousness (C);

- Emotional Instability (EI);

- Intellect/Openness (I/O).

Each of the five factors is represented with 13 items. Responses are given on a 5-point scale ranging from "almost never" to "almost always". The Serbian version of the scale was developed using the forward and back-translation procedure from English to Serbian, and reversed, with two independent translators. Consensus regarding differences in translation was achieved via the third translator.

\section{Procedure}

Participants completed a questionnaire battery within a broader study framework where their personality traits were assessed in the context of readiness to adopt other languages, tradition, and customs in a multilingual and multinational environment (Popović \& Radović, 2016). All participants completed the questionnaires within their school hours, under the same instruction manual. One of the reasons why we used the BFQ-C (Barbaranelli et al., 2003) to examine the personality of children is the comparability of the results with an earlier study conducted with their parents, in which the Big Five model was the theoretical framework for personality explanation (Popović \& Radović, 2015).

\section{Data Analysis}

Before the analysis, we examined the Mahalanobis distances for each of the items using the regression analysis, in order to ensure that the results are not improperly influenced by multivariate outliers. We identified 33 participants as multivariate outliers and removed them from the data (that way, we obtained the final $N=850$ respondents). Confirmatory factor 
analysis (CFA) was carried out in the AMOS program. Given the apparent deviation of the multivariate distribution from normal (Mardia's coefficient of multivariate kurtosis $>5$ ), all models were evaluated using the scaled Satorra-Bentler chi-squared test using a robust ML method (Satorra \& Bentler, 1994). To cross-validate the latent factor structure of the BFQ-C, the sample was randomly divided into two datasets $(N=425)$ and models were subsequently tested on both samples. From the original dataset, approximately $50 \%$ of random cases were extracted into a new dataset, using the SPSS option. To assess how well the CFA models represented the data, the following criteria were used as cut-offs for a good fit: CFI $>.90$, RMSEA and SRMR $<0.08$ (Brown, 2006).

\section{Results}

Following the original model proposed by Barbaranelli et al. (2003), previously validated in the Dutch (Muris et al., 2005), German (Essau et al., 2006), French (Olivier \& Herve, 2015) and Spanish language (Holgado-Tello, Carrasco-Ortiz, del Barrio-Gándara, \& Chacón-Moscoso, 2007), 65 items grouped around five factors were tested through CFA. The hypothesized model, however, did not obtain satisfactory fit indices, as shown in Table 1. Further, we evaluated the shorter version of the scale, as proposed by Markos \& Kokkinos (2017) on the Greek sample. The second model did not fit the data.

Table 1.

Model fit indicators for the hypothesized five-factor model

\begin{tabular}{lllllll}
\hline & $\mathrm{cmin} / \mathrm{df}$ & $\mathrm{p}$ & $\mathrm{GFI}$ & $\mathrm{CFI}$ & RMSEA & SMR \\
Original model $^{\mathrm{a}}$ & 3.67 & .000 & .806 & .748 & $.056(.054-.058)$ & .068 \\
Shortened model $^{\mathrm{b}}$ & 3.62 & .000 & .868 & .755 & $.055(.051-.058)$ & .067 \\
\hline
\end{tabular}

Note: CFI $=$ the comparative fit index $(\geq .95$ indicates good fit); GFI $=$ goodness of fit index ( $\geq .95$ indicates good fit); RMSEA $=$ the root of the average square error approximation ( $\leq .05$ points to good fit, .08 to acceptable); ${ }^{\mathrm{a}}$ - The model proposed by Barbaranelli et al. (2003), ${ }^{\text {b }}$ - The model proposed by Markos \& Kokkinos (2017).

Following these results, we opted for a further exploration of the Serbian version of the BFQ-C's latent structure. Since previous validation studies suggested items reduction (Markos \& Kokkinos, 2017), we sought to remove items based on the following criteria for practical and statistical significance (Hier et al., 2006):

- items with factor loadings <.40;

- items with cross-loadings(with the difference higher than .20);

- items that were redundant. 
By inspecting the wording, after the translation procedure had been completed, some items resulted in almost identical wording due to language differences. For example (Extraversion: I like to be with others and removed: I like to meet with other people). This resulted in the final 29-items solution, with loadings on five factors. The same dataset was used to examine the Five-Factor Model with 29 items, and the second dataset was used as a cross-validation sample. Fit indicators, on both datasets, are presented in Table 2.

Table 2.

Model fit indicators for the proposed five-factor model with 29 items

\begin{tabular}{lcccccc}
\hline & $\mathrm{cmin} / \mathrm{df}$ & $\mathrm{p}$ & GFI & CFI & RMSEA & SRMR \\
\hline${\text { five-factor } \text { model }^{\mathrm{a}}}^{\mathrm{b}}$ & 2.41 & .000 & .900 & .902 & $.047-.058$ & .065 \\
five-factor model $^{\mathrm{b}}$ & 2.11 & .000 & .887 & .854 & $.046-.056$ & .064 \\
five-factor model $^{\mathrm{c}}$ & 1.92 & .000 & .906 & .894 & $.041-.052$ & .061 \\
\hline
\end{tabular}

Note: CFI $=$ the comparative fit index $(\geq .95$ indicates good fit $)$, GFI $=$ goodness of fit index ( $\geq .95) ;$ RMSEA = root mean square error of approximation; $(<.08) ;{ }^{a}$ the model tested on the first (calibrating) dataset, ${ }^{b}$ the model tested on the second (cross-validating) dataset; ${ }^{c}$ the model with correlated errors tested on the second dataset.

As can be noted above, the first model yielded satisfactory fit indices. Indicators of absolute fit (RMSEA, GFI) and parsimonious fit (Chisq/df) achieved the required levels. The indicator of incremental fit (CFI) reached the value above the recommended criterion of $>.90$ only for the model tested in the first dataset. The model tested on the second dataset showed lower values for incremental (CFI) and absolute (GFI) fit than recommended. An examination of modification indices suggested setting covariances on the error variances of items 13 ("I am sad") and 23 ("I can cry easily"). After allowing for this modification, the model fit improved.

However, based on Cheung and Rensvold's (2002) suggestions that more complex models (that is, the models with more items and more factors) affect most of the GFIs, except for RMSEA, and produce smaller values, we decided to interpret these values as overall satisfactory. Moreover, it is suggested in the pertinent literature that, when it comes to personality scales, the cut-off values for fit indices are often "unrealistic for complex measures to achieve on a sample independent from that with which they were developed", which is especially true for the indicators of incremental fit (Perry, Nicholls, Clough, \& Crust, 2015).

Factor loadings and proportions of explained variance for all items on both subsamples are shown below (Table 3 ). 
Table 3.

Standardized factor loadings and the proportion of explained variance for all items (BFQ-C-29)

\begin{tabular}{|c|c|c|c|c|c|c|c|c|c|c|}
\hline & \multicolumn{5}{|c|}{ First dataset } & \multicolumn{5}{|c|}{ Second dataset } \\
\hline & 1 & 2 & 3 & 4 & 5 & 1 & 2 & 3 & 4 & 5 \\
\hline BFQ-C48 & .693 & & & & & .658 & & & & \\
\hline BFQ-C3 & .677 & & & & & .616 & & & & \\
\hline BFQ-C39 & .572 & & & & & .523 & & & & \\
\hline BFQ-C16 & .529 & & & & & .522 & & & & \\
\hline BFQ-C19 & .507 & & & & & .457 & & & & \\
\hline BFQ-C27 & .443 & & & & & .496 & & & & \\
\hline BFQ-C34 & & .825 & & & & & .736 & & & \\
\hline BFQ-C23 & & .703 & & & & & .716 & & & \\
\hline BFQ-C47 & & .526 & & & & & .484 & & & \\
\hline BFQ-C6 & & .440 & & & & & .522 & & & \\
\hline BFQ-C25 & & .475 & & & & & .488 & & & \\
\hline BFQ-C41 & & .435 & & & & & .511 & & & \\
\hline BFQ-C46 & & & .722 & & & & & .706 & & \\
\hline BFQ-C45 & & & .767 & & & & & .652 & & \\
\hline BFQ-C43 & & & .644 & & & & & .549 & & \\
\hline BFQ-C32 & & & .459 & & & & & .358 & & \\
\hline BFQ-C15 & & & .361 & & & & & .455 & & \\
\hline BFQ-C1 & & & .355 & & & & & .403 & & \\
\hline BFQ-C29 & & & & .723 & & & & & .700 & \\
\hline BFQ-C9 & & & & .544 & & & & & .571 & \\
\hline BFQ-C21 & & & & .526 & & & & & .586 & \\
\hline BFQ-C37 & & & & .497 & & & & & .487 & \\
\hline BFQ-C13 & & & & .487 & & & & & .521 & \\
\hline BFQ-C44 & & & & .435 & & & & & .442 & \\
\hline BFQ-C14 & & & & & .687 & & & & & .676 \\
\hline BFQ-C10 & & & & & .609 & & & & & .597 \\
\hline BFQ-C36 & & & & & .519 & & & & & .484 \\
\hline BFQ-C28 & & & & & .370 & & & & & .298 \\
\hline BFQ-C31 & & & & & .271 & & & & & .402 \\
\hline
\end{tabular}

Note: ${ }^{a}$ the first dataset, ${ }^{b}$ the second dataset; 1 - Conscientiousness, 2 - Emotional instability, 3 - Extraversion, 4 - Agreeableness, 5 - Intellect/Openness 
Table 4.

Intercorrelations among the measured variables

\begin{tabular}{lcccc}
\hline & $\begin{array}{c}\text { Emotional } \\
\text { Instability }\end{array}$ & Agreeableness & Conscientiousness & $\begin{array}{c}\text { Intellect/ } \\
\text { Openness }\end{array}$ \\
\hline Extraversion & -.144 & .690 & .594 & .387 \\
Emotional & & -.071 & -.105 & -.164 \\
Instability & & & .759 & .533 \\
Agreeableness & & & & .681 \\
Conscientiousness & & & & \\
Intellect/Openness & & & & \\
\hline
\end{tabular}

\section{Descriptive indicators}

To test for normality, we used the Kolmogorov-Smirnov test together with the values of skewness and kurtosis (with a general rule for normality: kurtosis $\sim 3$ and skewness: -1 to 1 ). Results are shown for both, the total scale and each subscale (Table 4). Although Kolmogorov-Smirnov statistic appeared significant, the values of skewness and kurtosis suggest no alarming deviations.

Table 5.

Descriptive statistics for the SBFQ-C -29 scale

\begin{tabular}{lccrrrrrc}
\hline & \multicolumn{1}{l}{ K-S } & \multicolumn{1}{l}{ p Min } & \multicolumn{1}{c}{ Max } & \multicolumn{1}{c}{$M$} & \multicolumn{1}{c}{$S D$} & \multicolumn{1}{c}{ Skewness } & Kurtosis \\
\hline SBFQ-C-29 & .063 & .000 & 54.00 & 133.00 & 101.43 & 12.46 & -.422 & .699 \\
Intellect/Openness & .072 & .000 & 4.00 & 20.00 & 13.23 & .22 & -.194 & -.202 \\
Extraversion & .100 & .000 & 8.00 & 25.00 & 0.6 & .92 & -.644 & .492 \\
Conscientiousness & .068 & .000 & 7.00 & 30.00 & 21.02 & .25 & -.224 & -.340 \\
Emotion. instability & .086 & .000 & 6.00 & 30.00 & 16.02 & .25 & .282 & -.488 \\
Agreeableness & .101 & .000 & 6.00 & 30.00 & 22.73 & .15 & -.768 & .938 \\
\hline
\end{tabular}

Note: $\mathrm{K}-\mathrm{S}=$ Kolmogorov-Smirnov statistic; $p=$ sig. of Kolmogorov-Smirnov test; $M-$ mean; $S D$ - standard deviation

Table 6.

Item level descriptive statistics $(N=425)$

\begin{tabular}{llllll}
\hline SBFQ-29 items & Original items & $\mathrm{M}$ & $\mathrm{SD}$ & Skewness & Kurtosis \\
\hline 1 & BFQ-C1 & 4.77 & .54 & -2.70 & 7.75 \\
2 & BFQ-C3 & 3.90 & .95 & -.63 & -.07 \\
3 & BFQ-C6 & 2.30 & 1.30 & .63 & -.76 \\
4 & BFQ-C9 & 4.22 & .86 & -.93 & .41 \\
5 & BFQ-C10 & 3.58 & 1.03 & -.52 & -.09 \\
6 & BFQ-C13 & 4.00 & 1.11 & -1.10 & .52 \\
7 & BFQ-C14 & 3.76 & 1.09 & -.59 & -.30 \\
8 & BFQ-C15 & 4.49 & .84 & -1.81 & 3.06 \\
9 & BFQ-C16 & 4.31 & .87 & -1.25 & 1.36 \\
\hline
\end{tabular}




\begin{tabular}{llllll}
\hline SBFQ-29 items & Original items & $\mathrm{M}$ & $\mathrm{SD}$ & Skewness & Kurtosis \\
\hline 10 & BFQ-C19 & 2.75 & 1.34 & .18 & -1.18 \\
11 & BFQ-C21 & 4.15 & .93 & -.98 & .46 \\
12 & BFQ-C23 & 3.02 & 1.34 & -.00 & -1.16 \\
13 & BFQ-C25 & 2.10 & 1.32 & .87 & -.54 \\
14 & BFQ-C27 & 4.16 & .93 & -1.03 & .59 \\
15 & BFQ-C28 & 3.04 & 1.33 & -.10 & -1.10 \\
16 & BFQ-C29 & 4.01 & .83 & -.75 & .72 \\
17 & BFQ-C31 & 3.49 & 1.13 & -.50 & -.44 \\
18 & BFQ-C32 & 3.54 & 1.06 & -.58 & -.12 \\
19 & BFQ-C34 & 2.85 & 1.22 & .09 & -.90 \\
20 & BFQ-C36 & 2.89 & 1.22 & -.00 & -.93 \\
21 & BFQ-C37 & 3.25 & 1.15 & -.27 & -.69 \\
22 & BFQ-C39 & 2.92 & 1.34 & -.04 & -1.14 \\
23 & BFQ-C41 & 2.54 & 1.44 & .32 & -1.34 \\
24 & BFQ-C43 & 4.29 & .79 & -1.27 & 1.94 \\
25 & BFQ-C44 & 3.58 & 1.06 & -.54 & -.18 \\
26 & BFQ-C45 & 4.03 & .92 & -.77 & .03 \\
27 & BFQ-C46 & 4.01 & .96 & -.84 & .24 \\
28 & BFQ-C47 & 3.28 & 1.31 & -.38 & -.96 \\
29 & BFQ-C48 & 3.76 & 1.01 & -.68 & .05 \\
\hline
\end{tabular}

\section{Reliability}

The reliability (internal consistency) was satisfactory for the BFQ-C total scale $(\alpha=.864)$; however, for separate subscales, Cronbach's alphas ranged from .584 (Intellect/Openness) to .753 (Conscientiousness). As shown in Table 5 , the shortened version of the scale can be considered as overall reliable and representative, as well as homogenous.

Table 7.

Reliability, adequacy and homogeneity of the SBFQ-C-29

\begin{tabular}{lcccc}
\hline & $\alpha$ & MSA & $\mathrm{h}^{1}$ & $\mathrm{~S}-\mathrm{B}$ \\
\hline SBFQ-C29 & .819 & .835 & .806 & .822 \\
Intellect/Openness & .584 & .695 & .592 & .605 \\
Extraversion & .729 & .707 & .700 & .715 \\
Conscientiousness & .753 & .789 & .730 & .737 \\
Emotional instability & .749 & .757 & .752 & .753 \\
Agreeableness & .691 & .806 & .715 & .725 \\
\hline
\end{tabular}

Note: $\alpha$ = Cronbach's alpha coefficient; MSA - Kaiser-Meyer-Olkin Measure of Sampling Adequacy; $\mathrm{h}^{1}$ - average inter-item correlation as a homogeneity indicator; S-B - Spearman-Brown split-half reliability coefficient 


\section{Multi-group analysis}

In order to determine the degree to which the factor loadings and intercepts of the specified model are equivalent across groups, we conducted a multi-group analysis using SPSS-AMOS. We tested for the configural, metric and scalar invariance across language (Serbian native/non-native) and gender (male/female).

The results of the multi-group analysis, for both language and gender, are shown in Table 8.

Table 8.

Multi-group analysis indicators

\begin{tabular}{lcccccccccc}
\hline & \multicolumn{1}{c}{ Language } & \multicolumn{1}{c}{ Gender } \\
& $\chi^{2} / \mathrm{df}$ & GFI & CFI & RMSEA & SRMR & $\chi^{2} /$ df & GFI & CFI & RMSEA & SRMR \\
\hline CNF & 2.25 & .902 & .880 & $.036(.034-.039)$ & .07 & 2.10 & .902 & .881 & $.035(.033-.038)$ & .06 \\
MTR & 2.21 & .901 & .881 & $.035(.033-.038)$ & .07 & 2.09 & .899 & .877 & $.035(.032-.038)$ & .07 \\
SCL & 2.19 & .901 & .873 & $.035(.033-.038)$ & .07 & 2.02 & .893 & .876 & $.034(.032-.037)$ & .07 \\
\hline
\end{tabular}

Note: $\chi 2 / \mathrm{df}=$ ratio chi square/degree of freedom; CFI = Confirmatory Fit Index $(\geq 0.90)$;

GFI $=$ Goodness of fit Index $(\geq 0.95)$; SRMR $=$ Standardized Root Mean Square Residual $(\leq 0.08)$; RMSEA = Root Mean Square Error of Approximation $(\leq 0.08)$; CNF - Configural invariance, MTR - Metric invariance, SCL - Scalar invariance

MGA across language. The difference between the first two models was found to be non-significant $\left(\Delta \chi^{2}\right.$ configural invariance $=19,385, \mathrm{p}=.62 ; \Delta \chi^{2}$ metric invariance $=14.38, \mathrm{p}=.51)$, while the results showed that the BFQ across language (Serbian native or non-native) was not a scalar invariant $\left(\Delta \chi^{2}\right.$ metric-scalar $=88.40, \mathrm{p}=.00$ ). However, while $\mathrm{cmin} / \mathrm{df}$, SRMR and RMSEA values were within satisfactory range of fit, the rest of the observed indices (CFI, GFI) showed that the data fitted poorly with the proposed factor structure.

In order to identify the non-invariant parameters, the forward method (sequentially adding parameters) was used. This revealed that only the residuals for the item BFQ-C45 and BFQ-C43, had loadings on the Extraversion factor, as well as that the BFQ-C44 from the Agreeableness factor, BFQ-C23 from the Neuroticism factor, and BFQ-C28 from the Intellect factor, should be unconstrained. When these parameters are let to vary freely, scalar invariance of the model is achieved $\left(\Delta \chi^{2}\right.$ metric invariance $=67.509, \mathrm{p}=.46$ ); still, incremental fit indices remained below acceptable fit.

MGA across gender. Results from Table 8 show that the model did not reach configural invariance. Significant difference between the first two models (configural and metric invariance, $\Delta \chi^{2}=41.87, \mathrm{p}<.01$ ) was yielded, suggesting that there is a significant difference in the factor structure of the construct across gender. 


\section{Discussion}

The Big Five model is probably the most used theoretical model for explaining adult personality. However, can the personality traits of children and adolescents be described by the same model? Precisely with that goal, as well as with the aim of creating a self-report assessment of personality of/for children and adolescents, Barbaranelli et al. (2003) constructed the BFQ-C scale. The original Italian version of the questionnaire was translated into several languages and used in many countries. Some authors tried to develop its shorter version (Markos \& Kokkinos, 2017) because the original 65-item instrument might be overlong for research purposes as well as for the target population. For the broader study (Popović \& Radović, 2016), we translated and used the BFQ-C (Barbaranelli et al., 2003) in assessing personality characteristics of preadolescent and adolescent-aged subjects. Although the five-factor solution was shown to be replicable across different languages, previous literature suggests certain structure instability of an entire scale (Gaio, 2012). Hence, the primary goal of the current study was to investigate some of the psychometric properties of the BFQ-C in the Serbian-speaking sample.

Our results on both datasets used in this study suggest that the latent empirical structure of the BFQ-C instrument corresponds to the theoretical "Big Five" model, thus supporting the multi-dimensional nature. In line with that, we preserved the hypothesized five-factor structure consisting of Energy/ Extraversion, Agreeableness, Conscientiousness, Emotional Instability, and Intellect/Openness, but we opted for the shortened version of the scale. Although the shortened version in the Serbian language is somewhat different from the previous suggestions (Markos \& Kokkinos, 2017), the content of the extracted factors remained the same. It seems plausible that the main underlying structure of personality traits followed the general principle (Kakabaraee, Moradi, Arjmandnia, Afrooz, \& Hooman, 2011). However, the specificity of different cultural contexts is reflected in minor deviations across studies.

Our results also suggest that the SBFQ-C29 has satisfactory internal consistency, homogeneity, and adequacy, which is consistent with previous studies addressing different cultures and languages (Muris et al., 2005; Kakabaraee et al., 2011). However, when it comes to separate subscales, four factors kept out of five were found to have adequate reliability for exploratory research. Specifically, the Intellect factor appeared to be the most unstable. The consistency with the previous findings suggests difficulties with this factor. Similar to our results, previous studies have shown that Intellect appears to share features with other factors from the model (i.e., Extraversion, and Conscientiousness) (Barbanelli et al., 2003; Muris et al., 2005). In the mentioned research, Intellect/Openness was divided into two clusters, one closer to academic achievement, which was related to Conscientiousness, and 
the other closer to curiosity and external stimulation, related to Extraversion. Moreover, there has been a long-continuing debate on the necessity of including Intellect/Openness as a separate personality dimension (Eysenck, 1992). Barbaranelli et al. (2003) refer to this factor as a reflection of an overall "problem with the heterogeneity of this Big Five factor" (Muris et al., 2005, p. 1766). As this factor raises attention among authors, and its structure has repeatedly been called into question, future research efforts may include and inspect additional items that might contribute to the overall strength of the empirical model fit.

The multi-group analysis was carried out to examine the measurement of invariance, taking into account the heterogeneity of the sample when it comes to the ethnicity, i.e. the maternal language of the respondents. The groups based on the maternal language are not different at the model level, but they may be different in the strength of the model. However, the same analysis in the context of gender shows that the factor structure of the questionnaire differs in relation to gender.

One of the main strengths of this study is the diversity and size of our sample. However, several limitations should be mentioned. While some of the studies in other-language speaking areas (e.g., Greek, Dutch, Spanish) were based on both self-reports and parent/teacher reports, we relied on the participants' self-reports only. As shown in previous studies, the inclusion of teacher/parent reports, as well as the behavioural indicators, could contribute to delivering more precise information about the psychometric properties of the instrument. Another significant limitation is that the study did not include a test of convergent validity of the instrument.

Despite the limitations mentioned above, our results should be regarded as a valuable contribution to the investigations of cross-cultural aspects of the BFQ-C, as well as an addition to the research of some psychometric properties of this instrument. It should be taken into account that this is a preliminary study. Altogether, our findings suggest that the SBFQ-C29 is a potentially useful tool for assessing personality traits in children and adolescents, but with a strong recommendation for the further investigation of external validity of the instrument.

\section{References}

Barbaranelli, C., Caprara, G. V., Rabasca, A., \& Pastorelli, C. (2003). A questionnaire for measuring the Big Five in late childhood. Personality and Individual Differences, 34, 645-664. https://doi.org/10.1016/s0191-8869(02)00051-x

Brown, T. A. (2006). Confirmatory factor analysis for applied research. New York, NY: Guilford Press.

Cheung, G. W., \& Rensvold, R. B. (2002). Evaluating goodness-of-fit indexes for testing measurement invariance. Structural equation modeling, 9 (2), 233-255. https://doi.org/10.1207/S15328007SEM0902_5 
Costa, P. T., Jr., \& McCrae, R. R. (1992). Normal personality assessment in clinical practice: The NEO Personality Inventory. Psychological Assessment, 4, 5-13. https://doi.org/10.1037//1040-3590.4.1.5

Cupani, M. \& Ruarte, M. (2008) Psychometric properties of the Big Five Questionnaire for Children (BFQ-C) in an Argentine sample of young adolescents. Studies in Psychology, 29(3), 351-364. https://doi.org/10.1174/021093908786145421

Čolović, P., Mitrović, D. i Smederevac, S. (2005). Evaluacija modela Pet velikih u našoj kulturi primenom upitnika FIBI [Evaluation of the Big Five model in Serbian culture using the FIBI questionnaire]. Psihologija, 38, 55-76.

Essau, C. A., Sasagawa, S., \& Frick, P. J. (2006). Callous-unemotional traits in a community sample of adolescents. Assessment, 13, 454-469. https://doi. org/10.1177/1073191106287354

Eysenck, H. J., \& Eysenck, S. B. G. (1975). Manual of the Eysenck Personality Questionnaire. London, England: Hodder \& Stoughton.

Gaio, V. (2012). Psychometric Properties of the Big Five Questionnaire-Children (BFQ-C) in American Adolescents(master thesis). Arizona State University.

Goldberg, L.R. (1993). The structure of phenotypic personality traits. American Psychologist, 48 (1), 26-34. https://doi.org/10.1037//0003-066x.48.1.26

Gorsuch, R. L. (1997). Exploratory factor analysis: its role in item analysis. Journal of Personality Assessment, 68(3), 532-560.

Gresham, D., \& Gullone, E. (2012). Emotion regulation strategy use in children and adolescents: The explanatory roles of personality and attachment. Personality and Individual Differences, 52(5), 616-621.https://doi.org/10.1016/j.paid.2011.12.016

Holgado-Tello, F.P., Carrasco-Ortiz, M.Á., del Barrio-Gándara, M.V. et al. (2009). Factor analysis of the Big Five Questionnaire using polychoric correlations in children. Quality and Quantity, 43, 75-85. https://doi.org/10.1007/s11135-0079085-3

Kakabaraee, K., Moradi, A. R., Arjmandnia, A. A., Afrooz, G. A., \& Hooman, H. A. (2011). Short Version of the Big Five inventory: testing for the factorial invariance across parents with normal and exceptional children. International Journal of Psychology, 5(1), 73-99.

Kokkinos, C. M., \& Markos, A. (2015). The big five questionnaire for children (BFQC). European Journal of Psychological Assessment, 33, 129-133. https://doi. org/10.1027/1015-5759/a000273

Markos, A., \& Kokkinos, C., M. (2017). Development of a Short Form of the Greek Big Five Questionnaire for Children (GBFQ-C-SF): Validation among Preadolescents. Personality and Individual Differences, 112, 12-17. https://doi. org/10.1016/j.paid.2017.02.045

Muris, P., Meesters, C., \&Diederen, R. (2005). Psychometric properties of the Big Five Questionnaire for Children (BFQ-C) in a Dutch sample of young adolescents. Personality and Individual Differences, 38, 1757-1769. https://doi.org/10.1016/j. paid.2004.11.018

Nunnally, J. (1978). Psychometric Theory (2nd Ed.). New York : McGraw-Hill. 
Olivier, M., \& Herve, M. (2015). The Big Five questionnaire for children (BFQ-C): A French validation on 8- to 14-year-old children. Personality and Individual Differences, 87, 55- 58. https://doi.org/10.1016/j.paid.2015.07.030

Pejić, M., Tenjović, L., \& Knežević, G. (2014). Validacija upitnika ličnosti BFI-10 - kratke forme Inventara Velikih pet (Validation of BFI-10 personality questionnaire - a short Big Five form). Primenjena psihologija, 7, 45-62. https://doi. org/10.19090/pp.2014.1.45-92

Perry, J. L., Nicholls, A. R., Clough, P. J., \& Crust, L. (2015). Assessing model fit: Caveats and recommendations for confirmatory factor analysis and exploratory structural equation modeling. Measurement in physical education and exercise science, 19(1),12-21. https://doi.org/10.1080/1091367x.2014.952370

Popov,S \& Radović,D. (2015). Unapređivanje obrazovanja na više jezika u multijezičkoj Vojvodini: Stavovi roditelja o višejezičnosti u osnovnim školama [Development of plurilingual education in Vojvodina: Parents' attitudes to plurilinguality in primary schools]. Novi Sad: Pedagogical Institute of Vojvodina.

Popov,S \& Radović,D. (2016). Stavovi učenika osnovnih i srednjih škola prema učenju stranih jezika i jezika iz neposrednog okruženja [Primary and secondary students' attitudes towards learning foreign languages and languages spoken in their immediate environment]. Novi Sad: Pedagogical Institute of Vojvodina.

Satorra, A., \&Bentler, P. M. (1994). Corrections to test statistics and standard errors in covariance structure analysis. In A. van Eye \& C. C. Clogg (Eds.), Latent variable analysis in developmental research (pp. 285-305). Thousand Oaks, CA: SAGE Publications Inc.

Srivastava, S., John, O. P., Gosling, S. D., \& Potter, J. (2003). Development of personality in early and middle adulthood: Set like plaster or persistent change? Journal of Personality and Social Psychology, 84(5), 1041-1053. https://doi. org/10.1037/0022-3514.84.5.1041 


\section{Evaluacija interne strukture srpske verzije Velikih pet upitnika ličnosti za decu i razvoj kratke forme (SBFQ-C-29): Preliminarna studija}

\section{Stanislava Popov}

Fakultet za sport i turizam, Univerzitet Edukons, Novi Sad

\section{Jelena Sokić}

Fakultet za sport i turizam, Univerzitet Edukons, Novi Sad

\section{Danijela Radović}

Pedagoški zavod Vojvodine, Novi Sad

Karakterstike ličnosti dece i adolescenata objašnjene modelom Velikih pet proučavane su znatno manje nego karakteristike ličnosti odraslih. Jedan od retkih instrumenata za samoprocenu ličnosti u preadolescentnom i adolescentnom uzrastu je Velikih pet upitnik ličnosti za decu (BFQ-C). Cilj ovog istraživanja jeste evaluacija i prikaz latentne strukture i nekih psihometrijskih karakteristika instrumenta BFQ-C na srpskom jeziku. Uzorak se sastojao od 881 ispitanika (54\% ženskog pola) koji su pohađali završne razrede osnovne i početne razrede srednje škole $(M=14$ godina, $S D=.99)$. Originalni model koji je prethodno testiran u različitim kulturama i na različitim jezicima, testirali smo na našem uzorku koristeći konfirmatornu faktorsku analizu. Hipotetski model nije ostvario zadovoljavajuće indekse fita. Nakon ovoga, uzorak je randomizirano podeljen u dva seta podataka radi dalje eksploracije latentne strukture srpske verzije BFQ-C instrumenta, kao i razvoja njegove kratke forme. Finalni rezultat je solucija upitnika sa 29 tvrdnji (SBFQ-C-29), sa opterećenjima na pet faktora, sa zadovoljavajućom internom konzistentnošću, homogenošću i adekvatnošću, što je u saglasnosti sa prethodnim studijama rađenim na različitim kulturama i jezicima.

Key words: BFQ-C, interna struktura, srpska verzija 


\section{Appendix 1}

\section{SBFQ-C-29 GENDER: $\mathrm{f}$ m AGE}

This questionnaire contains items concerning human feelings, opinions and behaviours. Please mark the number that indicates how much you agree with every item. Numbers have the following meaning: 1 - ALMOST NEVER TO 5 - ALMOST ALWAYS

\begin{tabular}{|c|c|c|c|c|c|c|}
\hline & Items & \multicolumn{5}{|c|}{ Answers } \\
\hline 1 & I like to meet with other people. & 1 & 2 & 3 & 4 & 5 \\
\hline 2 & I do my job without carelessness and inattention. & 1 & 2 & 3 & 4 & 5 \\
\hline 3 & I am in a bad mood. & 1 & 2 & 3 & 4 & 5 \\
\hline 4 & I behave correctly and honestly with others. & 1 & 2 & 3 & 4 & 5 \\
\hline 5 & I easily learn what I study at school. & 1 & 2 & 3 & 4 & 5 \\
\hline 6 & I like to give gifts. & 1 & 2 & 3 & 4 & 5 \\
\hline 7 & When the teacher asks questions I am able to answer correctly. & 1 & 2 & 3 & 4 & 5 \\
\hline 8 & I like to be with others. & 1 & 2 & 3 & 4 & 5 \\
\hline 9 & I engage myself in the things I do. & 1 & 2 & 3 & 4 & 5 \\
\hline 10 & $\begin{array}{l}\text { When I finish my homework, I check it many times to see if I } \\
\text { did it correctly. }\end{array}$ & 1 & 2 & 3 & 4 & 5 \\
\hline 11 & I treat my peers with affection. & 1 & 2 & 3 & 4 & 5 \\
\hline 12 & I easily get offended. & 1 & 2 & 3 & 4 & 5 \\
\hline 13 & I am sad. & 1 & 2 & 3 & 4 & 5 \\
\hline 14 & If I take an engagement I keep it. & 1 & 2 & 3 & 4 & 5 \\
\hline 15 & $\begin{array}{l}\text { I like to watch TV news, and to know what happens in the } \\
\text { world. }\end{array}$ & 1 & 2 & 3 & 4 & 5 \\
\hline 16 & I am polite when I talk with others. & 1 & 2 & 3 & 4 & 5 \\
\hline 17 & I am able to create new games and entertainments. & 1 & 2 & 3 & 4 & 5 \\
\hline 18 & I am able to convince someone of what I think. & 1 & 2 & 3 & 4 & 5 \\
\hline 19 & I easily lose my calm. & 1 & 2 & 3 & 4 & 5 \\
\hline 20 & I am able to solve mathematics problems. & 1 & 2 & 3 & 4 & 5 \\
\hline 21 & I treat kindly also persons who I dislike. & 1 & 2 & 3 & 4 & 5 \\
\hline 22 & I play only when I finished my homework. & 1 & 2 & 3 & 4 & 5 \\
\hline 23 & I weep. & 1 & 2 & 3 & 4 & 5 \\
\hline 24 & I like to joke. & 1 & 2 & 3 & 4 & 5 \\
\hline 25 & I let other people use my things. & 1 & 2 & 3 & 4 & 5 \\
\hline 26 & I easily make friends. & 1 & 2 & 3 & 4 & 5 \\
\hline 27 & I am happy and lively. & 1 & 2 & 3 & 4 & 5 \\
\hline 28 & I worry about silly things. & 1 & 2 & 3 & 4 & 5 \\
\hline 29 & I do my own duty. & 1 & 2 & 3 & 4 & 5 \\
\hline
\end{tabular}




\section{Appendix 2}

\section{$\begin{array}{llll}\text { SBFQ-C-29 POL: } & \mathbf{m} & \check{z} & \text { STAROST }\end{array}$}

Ovaj upitnik sadrži tvrdnje koje se odnose na osećanja, mišljenja i ponašanja koja se susreću kod ljudi. Zaokruži broj koji najviše odgovara tvom slaganju sa svakom iznetom tvrdnjom. Brojevi imaju sledeće značenje: 1-UOPŠTE SE NE SLAŽEM do 5-POTPUNO SE SLAŽEM

\begin{tabular}{|c|c|c|c|c|c|c|}
\hline & Tvrdnje & \multicolumn{5}{|c|}{ Odgovori } \\
\hline 1 & Volim da provodim vreme sa drugima. & 1 & 2 & 3 & 4 & 5 \\
\hline 2 & Obavljam svoje zadatke pažljivo. & 1 & 2 & 3 & 4 & 5 \\
\hline 3 & Lošeg sam raspoloženja. & 1 & 2 & 3 & 4 & 5 \\
\hline 4 & Iskren/a sami fin/a sadrugima. & 1 & 2 & 3 & 4 & 5 \\
\hline 5 & Lako mi je da naučim ono što se u školi predaje. & 1 & 2 & 3 & 4 & 5 \\
\hline 6 & Volim da dajem poklone. & 1 & 2 & 3 & 4 & 5 \\
\hline 7 & $\begin{array}{l}\text { Kada nastavnik postavlja pitanja, u stanju sam da dam } \\
\text { ispravan odgovor. }\end{array}$ & 1 & 2 & 3 & 4 & 5 \\
\hline 8 & Volim da budem u društvu drugih. & 1 & 2 & 3 & 4 & 5 \\
\hline 9 & $\begin{array}{l}\text { Veoma sam predan/a kad nešto radim i radim najbolje što } \\
\text { mogu. }\end{array}$ & 1 & 2 & 3 & 4 & 5 \\
\hline 10 & $\begin{array}{l}\text { Kada završim domaći, proverim više puta da bih bio/la } \\
\text { siguran/na da sam ga dobro uradio/la. }\end{array}$ & 1 & 2 & 3 & 4 & 5 \\
\hline 11 & Prijatan/na sam prema svima u odeljenju. & 1 & 2 & 3 & 4 & 5 \\
\hline 12 & Lako se uvredim. & 1 & 2 & 3 & 4 & 5 \\
\hline 13 & Tužan/na sam. & 1 & 2 & 3 & 4 & 5 \\
\hline 14 & Kada nešto zakažem onda se toga i pridržavam. & 1 & 2 & 3 & 4 & 5 \\
\hline 15 & Volim da gledamvestina TV-u i da znam šta se u svetu događa. & 1 & 2 & 3 & 4 & 5 \\
\hline 16 & Ljubazan/na sam kada razgovaram sa drugima. & 1 & 2 & 3 & 4 & 5 \\
\hline 17 & $\begin{array}{l}\text { U stanju sam da izmislim nove igre i druge aktivnosti koje } \\
\text { mogu da se rade. }\end{array}$ & 1 & 2 & 3 & 4 & 5 \\
\hline 18 & U stanju sam da ubedim druge da se slože sa onim što ja mislim. & 1 & 2 & 3 & 4 & 5 \\
\hline 19 & Lako se uznemirim. & 1 & 2 & 3 & 4 & 5 \\
\hline 20 & U stanju sam da rešavam matematičke probleme. & 1 & 2 & 3 & 4 & 5 \\
\hline 21 & Tretiram sa ljubaznošću čak i one koji mi se ne sviđaju. & 1 & 2 & 3 & 4 & 5 \\
\hline 22 & $\begin{array}{l}\text { Uvek završim domaći pre nego što odem da se igram ili } \\
\text { zabavljam. }\end{array}$ & 1 & 2 & 3 & 4 & 5 \\
\hline 23 & Lako zaplačem. & 1 & 2 & 3 & 4 & 5 \\
\hline 24 & Volim da se šalim. & 1 & 2 & 3 & 4 & 5 \\
\hline 25 & Dozvoljavam drugima da koriste moje stvari. & 1 & 2 & 3 & 4 & 5 \\
\hline 26 & Lako se sprijateljim. & 1 & 2 & 3 & 4 & 5 \\
\hline 27 & Srećan/na sam i aktivan/na. & 1 & 2 & 3 & 4 & 5 \\
\hline 28 & Brinem oko glupih stvari. & 1 & 2 & 3 & 4 & 5 \\
\hline 29 & Vodim računa o svojim obavezama. & 1 & 2 & 3 & 4 & 5 \\
\hline
\end{tabular}

